\title{
New developments in the study of loess in China
}

Loess in China provides a good record of global change and has drawn extensive attention from geologists all over the world. By strengthening such research it may be possible to make new contributions to the study of global change.

Loess in China provides perhaps the most complete Quaternary continental record in the world. Among the most important past achievements are: compilation of typical profile maps in various areas; successful correlations between rock stratigraphy, biostratigraphy, climatostratigraphy and magnetostratigraphy; discovery of palaeoclimate cycles of loess-palaeosol dated at 2.5 Ma and correlated with deep-sea oxygen isotope records; establishment of a loess-palaeosol stratigraphic time scale tied to palaeomagnetic events and using improved dating techniques; and determination of the environmental evolution of the Loess Plateau.

In recent years, new understanding of loess stratigraphy has been obtained and short-term palaeoclimatic changes have been thoroughly studied. The semi-quantitative study of palaeoclimate has been successful and some inititial progress has been made in the study of spatial palaeoclimate variation based on studies of specific palaeosol layers.

\section{New understandings}

$\mathrm{B}_{\text {ased on recent research on two loess profiles in Huangling and }}$ Baoji, Shaanxi Provinces respectively, a stratigraphic classification and correlation according to magnetostratigraphy, spore-pollen biostratigraphy, soil climate stratigraphy, rock stratigraphy and chronostratigraphy are proposed (Figure 1).

\section{Magnetostratigraphy}

This is basically identical with the previously reported conclusions (Liu Tungshen et al., 1985; Zhang Zonghu et al., 1983). The main magnetostratigraphic boundaries are:

- The Brunhes/Matsuyama (B/M) boundary is in the lower part of loess layer $\mathrm{L}_{8}$;

- The top of Jaramillo event in the Matsuyama reversed epoch is near the juncture of palaeosol $\mathrm{S}_{10}$ and loess $\mathrm{L}_{11}$ and its bottom is in the middle of loess layer $\mathrm{L}_{13}$;

- The other boundaries are as previously reported.

In addition, at the top of Matsuyama reversed epoch (upper L9) there is a polar abnormal zone which received little attention in the past. Through analysis, it can be correlated with the 'B/M precursor'. In the upper part of $\mathrm{L}_{15}$, there is another short-term polar abnormal zone, which may be equivalent to the 'Cop Maintain'. The detection of these short-term abnormal phenomena is of great help in deter-

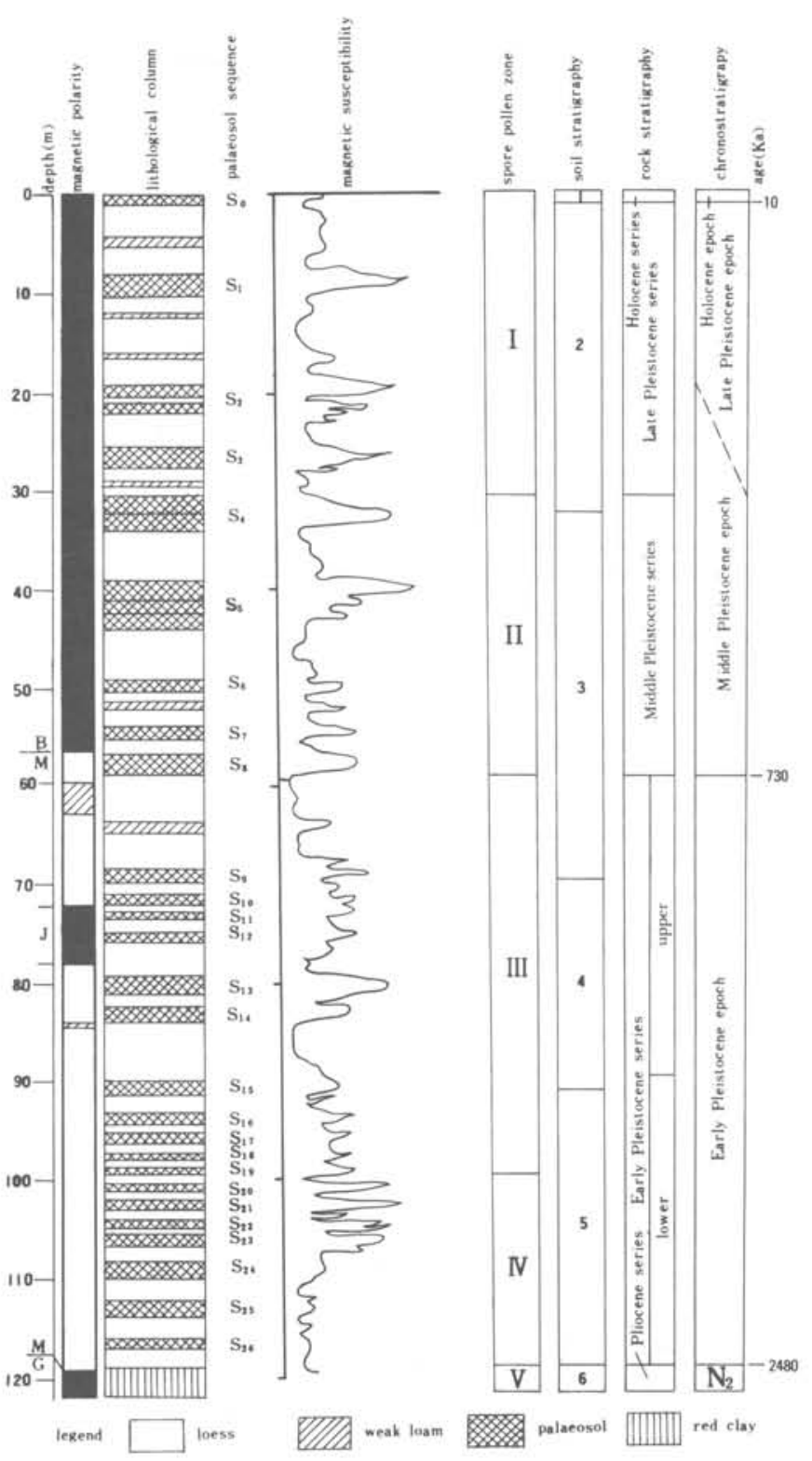

Figure 1 Stratigraphic divisions of a typical loess profile, Shaanxi, China.

mining the absolute time scale of loess sequences and making global comparisons of palaeoclimate and palaeoenvironment.

\section{Spore-pollen biostratigraphic divisions}

Four spore-pollen biological climate zones have been designated as follows:

1 from the top of profile to the top of palaeosol $\mathrm{S}_{4}$;

2 from palaeosol $\mathrm{S}_{4}$ to the bottom of palaeosol $\mathrm{S}_{8}$;

3 from $\mathrm{L}_{9}$ to $\mathrm{S}_{20}$, and

4 from $L_{21}$ to the bottom of whole loess profile. 
Table I Dominant soil types in various soil climate zones.

\begin{tabular}{|c|c|c|c|c|c|c|}
\hline Order & Dominant soil & Colour & Structure & Clay skin & Pore space & Representative bed \\
\hline 1 & black loam & $\begin{array}{l}\text { dark greyish } \\
\text { brown }\end{array}$ & & & & $S_{0}$ \\
\hline 2 & $\begin{array}{c}\text { deep-brown } \\
\text { earth }\end{array}$ & $\begin{array}{c}\text { deep brownish } \\
\text { yellow }\end{array}$ & columnat & abundant & more & $\mathrm{S}_{1}, \mathrm{~S}_{9}$ \\
\hline 3 & brown earth & $\begin{array}{c}\text { brownish yellow } \\
\text { deep brown }\end{array}$ & lump & less & less & $S_{\circ} . S_{\rtimes}$ \\
\hline 4 & brown earth & brownish yellow & granular & least & more & $S_{1 \downarrow}$ \\
\hline 5 & $\begin{array}{c}\text { brownish red } \\
\text { soil }\end{array}$ & brownish red & & none & less & $S_{20}$ \\
\hline
\end{tabular}

The numbers in column 1 are equvalent to those in Figure 1 , column 6.

\section{Soil climatic stratigraphic divisions}

Palaeosols are important components of loess sequences and contain a great amount of information about palaeoclimatic and palacoenvironmental change. From the view point of soil climate stratigraphy, five soil climate zones have been recognised. From the top to the bottom they are:

I $S_{0}$ (near the ground surface is a black loam layer);

2 from $L_{1}$ to the middle of $S_{4}$ :

3 from the middle of $S_{4}$ to the top of $S_{9}$;

4 from the top of $S_{9}$ to the bottom of $S_{15}$; and

5 from the bottom of $S_{15}$ to the bottom of whole loess sequences. The soil characteristics of each zone are shown in Table 1.

\section{Rock stratigraphic divisions}

Loess in China is transported and accumulated by various geological agents under certain climatic conditions and formed through loessification. The rock stratigraphic units have been divided on the basis of rock, loess and palaeosol properties.

1 Holocene series: composed of black loam layer $\left(S_{(0)}\right)$;

2 Late Pleistocene series: from the top of $\mathrm{L}_{1}$ to the bottom of $\mathrm{L}_{4}$;

3 Middle Pleistocene series: from $\mathrm{S}_{4}$ to the bottom of $\mathrm{L}_{4}$;

4 Early Pleistocene series:

upper part: from $S_{9}$ to the bottom of $L_{15}$ :

lower part: from $S_{15}$ to the bottom of loess accumulation.

\section{Chronostratigraphic divisions}

The chronostratigraphic divisions have been set according to the time scale determined by the magnetostratigraphic analysis and international correlation principles:

1 The $Q_{4} / Q_{3}$ boundary is at the bottom of $S_{0}$, at about $10 \mathrm{Ka}$;

2 With regard to the $\mathrm{Q}_{3} / \mathrm{Q}_{2}$ boundary, so far there is no clear evidence. It is temporarily placed somewhere between $S_{2}$ and $S_{4}$ based on rock-and biostratigraphy. A precise age for this boundary has yet to be determined;

3 The $Q_{2} / Q_{1}$ boundary is determined to be at the top of $S_{8}$ by magnetostratigraphic chronology, about $0.73 \mathrm{Ma}$;

4 The $\mathrm{Q}_{1} / \mathrm{N}$ boundary is at the bottom of the loess sequence, coincident with the Matsuyama/Gauss polarity boundary of $2.48 \mathrm{Ma}$.

\section{New progress}

Palaeoclimate research on loess in China began several decades ago and some advances in the understanding of Quaternary climatic changes have been made. For example, the use of high-precision dating techniques. have led to the establishment of short-duration palacoclimatic changes. By means of correlation analysis, past climatic change has been quantified, and based on a study of time sequences, the spatial regularities of palaeoclimatic evolution have been probed.

Further understanding of past global changes requires a strengthening of research on the last glacial-interglacial cycle and on post-Holocene continental records to complement the palaeoclimatic interpretation of loess in China for these time periods.

It is well known that the magnetic susceptibility of loess strata can reflect climatic changes and this has already been used in correlation between land and ocean and in research into past global changes (Heller et al., 1984: Kukla, 1987). With this index and high-precision dating method, the climatic evolution since the Holocene epoch in the Loess Plateau has been analysed and it is found that there were low-frequency climatic fluctuations of relatively short span in the Holocene (Figure 2). The analysis shows that the climate in the Loess Plateau began to become warmer after the last pleniglacial. During that period, around 10.3 Ka, a sudden drop in temperature within a very short time, occurred. possibly in the Younger Dryals stade. Afterwards, the temperature continued to rise very slowly. At approximately $9.3 \mathrm{Ka}$, the speed evidently quickened, heralding a postglacial optimal period which lasted until $6.7 \mathrm{Ka}$. However, this high-temperature period was not stable. There were three relatively cold periods, and two small fluctuations of cold climate, that is to say, during the period $9.3-6.7 \mathrm{Ka}$ there were second-order low-frequency fluctuations in climate against a general warm-humid background and also the climate became warmer and warmer reatching a peak around $6.7 \mathrm{Ka}$. After that, the postglacial optimal period ended and the temperature began

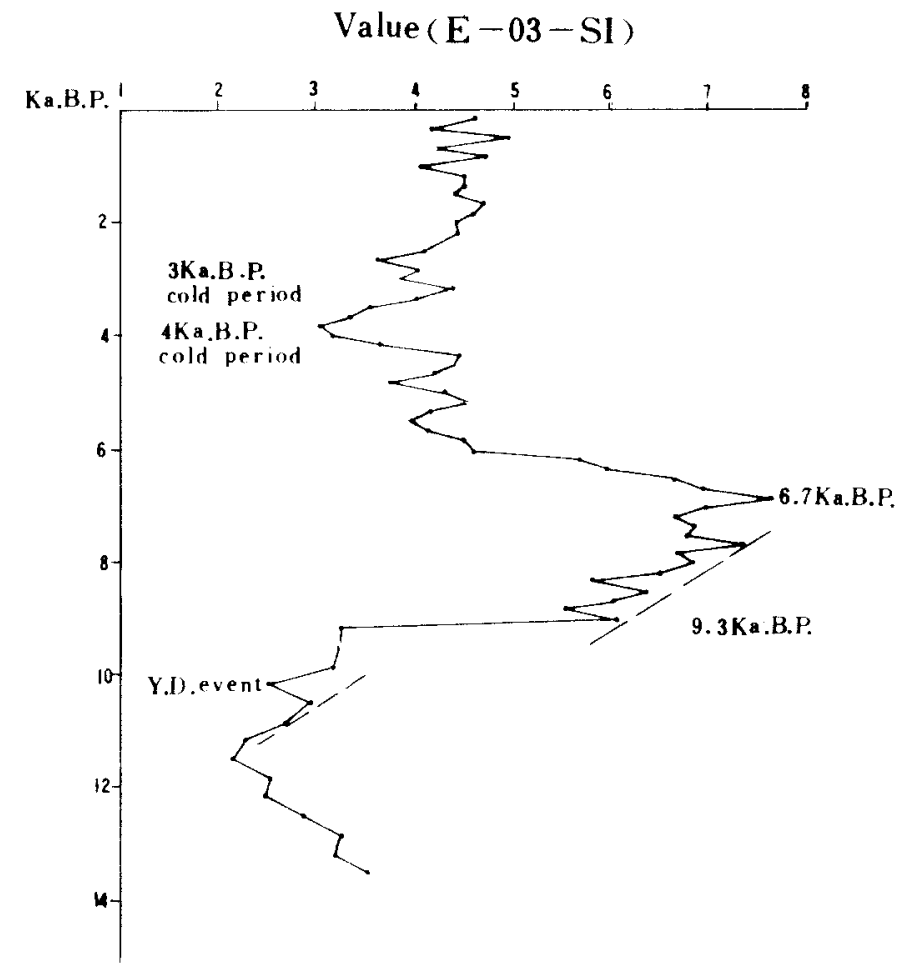

Figure 2 Holocene magnetic susceptibility curve for loess of the Loess Plateau. Y.D. = Younger Dryas 
to fall until $5.5 \mathrm{Ka}$. Since then, the climate has fluctuated frequently against a background which was cooler than in the optimal period. Two more evident cold periods occcurred around $4 \mathrm{Ka}$ and $3 \mathrm{Ka}$ respectively.

These basic features of Holocene climate recorded by the loess, including the unstability of climate in the warm period 9.3-6.7 Ka and the cold periods in $4 \mathrm{Ka}$ and $3 \mathrm{Ka}$, can be correlated with the Holocene climate records in other regions of China (Kukla, 1987; Wu Xihao et al., 1994) and also with the cold periods divided by glaciers since the Holocene epoch in the Northern Hemisphere (Denton et al., 1993).

Palaeoclimatic research on loess in China occupies an important place in the study of global change. From the loess-palaeosol sequences, many indices reflecting palaeoenvironmental change can be obtained and analysis of these indices can provide concrete evidence of past environmental change. The annual average temperature and the annual average precipitation in the last interglacial stage of some areas of the Loess Plateau has been investigated in accordance with the relationship between modern surface spore-pollen and climate. At the same time, an equation describing the relationship between the ferric oxide content in the profiles and local modern average precipitation and temperature has been obtained:

- $\mathrm{Y}=(245.675)(\mathrm{X})(-648.787) \quad$ (fitting degree 0.779)

- $\mathrm{Y}^{1}=(5.8)(\mathrm{X})(-32.99) \quad$ (fitting degree 0.759)

where $\mathrm{Y}$ is the annual average precipitation $(\mathrm{mm})$;

$\mathrm{Y}^{1}$ is the average temperature $\left({ }^{\circ} \mathrm{C}\right)$ in January, and

$\mathrm{X}$ is the percentage of ferric oxide.

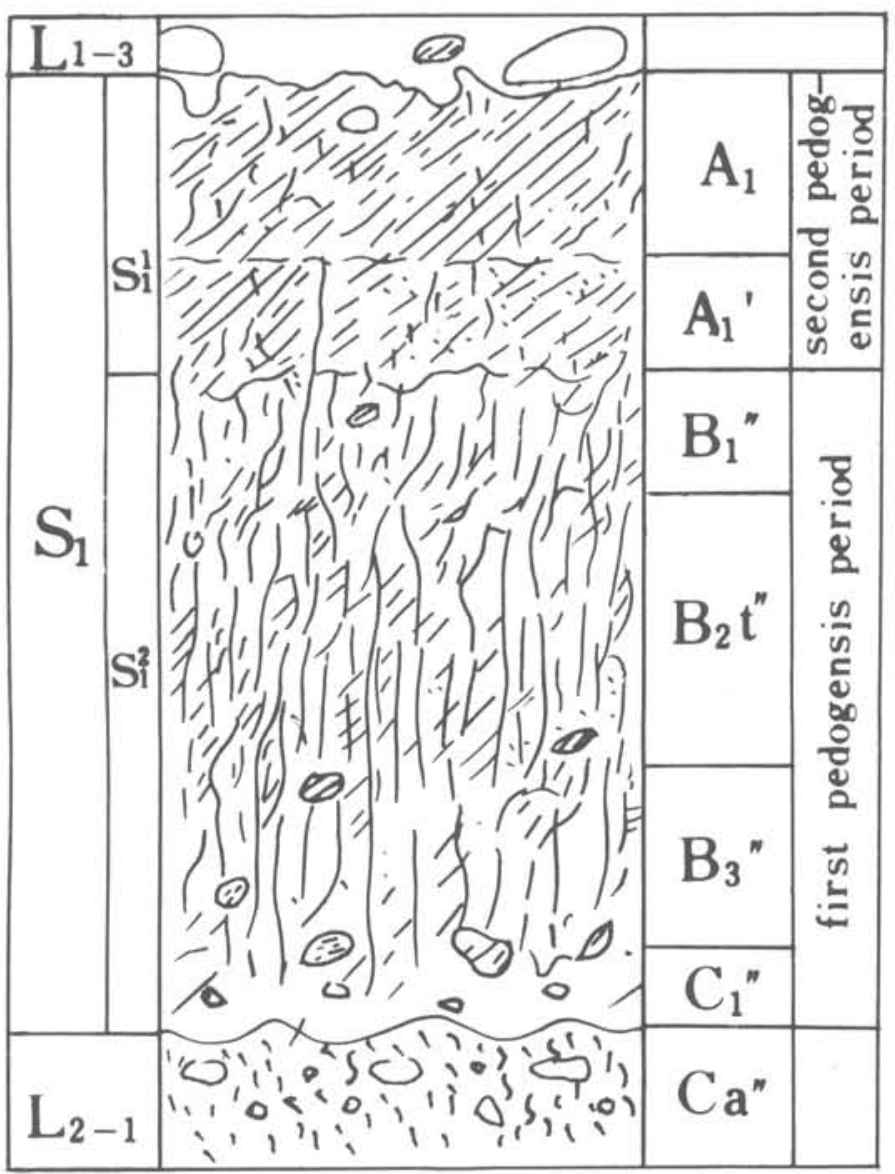

Figure 3 Compound palaeosol section through the Huangling profile S1. L Loess; S Palaeosol
Calculated from the above equations, the annual average precipitation in the Holocene high-temperature period in the central Loess Plateau was $200 \mathrm{~mm}$ more than it is nowadays and the average temperature in January was $3^{\circ} \mathrm{C}$ higher.

The pedological study of loess-palaeosol sequences and the analysis of palaeoclimatic changes from pedogenic data have met with further success in China in recent years. The climate conditions in various regions have been compared through the first palaeosol layer of the Loess Plateau. The results show that this palaeosol is composite and formed during successive periods in which various pedogenic processes operated (Figure 3 ).

Judged by observations in the profiles of factors such as the leaching and precipitation of $\mathrm{CaCO}_{3}$, the precipitaion of ferric oxide and ferric hydroxide and the distribution of clay skin etc., there were two periods of pedogenesis with contrasting climates. The contents of $\mathrm{Al}_{2} \mathrm{O}_{3}, \mathrm{Fe}_{2} \mathrm{O}_{3}$ and $\mathrm{FeO}$ in the soil during the first period were evidently higher than in the second period and the $\mathrm{B}$ layer in the first period became completely decalcified.The soil in the first period was mainly argillic (Bt) while that in the second period was still at the leaching stage (A). This fully demonstrates that temperature and humidity in the first period were markedly higher than in the second one. Further, the climatic conditions in different areas in the same period were also different. For instance, during the first pedogenic period, the climate indicated by the Huangling S1 profile was northern sub tropical while the Xifeng S1 profile indicates southern warm moderate conditions.

For a long time, particular emphasis was laid on time sequences in palaeoclimate research on loess in China. However, such research may also lead to an understanding of the spatial distribution of climatic zones in a specific period. How to further understand these spatial patterns and their mechanisms of formation is no doubt the main challenge to be faced in the future.

\section{References}

Denton, G A et al., 1993, Holocene climatic variations-their pattern and possible cause: Quaternary Research, no. 3, pp. 155-205

Heller, F and Liu, T S, 1984, Magnetism of Chinese loess deposits: Journal of Geophysical Research, v. 77, pp. 125-141

Kukla, G and An Zhisheng, 1989, Loess stratigraphy in Central China: Palaeogeology, Palaeoclimatology, Palaeoecology, v. 72, pp. 203-225

Kukla, G, 1987, Loess stratigraphy in Central China: Quaternary Science Reviews, v. 6, pp. 191-219

Liu Tungshen et al., 1985, Loess and environment, Science Press, pp. 44-62; $413-423$.

Liu, X M et al., 1987, A preliminary study on magnetostratigraphy of a loess profile in Xifeng area, Gansu Province, in Liu T S, ed., Aspects of loess research, pp.164-174.

Shi Yafeng et al., 1992, Climate and environment during big warm period of Holocene Epoch in China: China Ocean Press, pp.1-17.

Shi Yafeng et al., 1992, Climate fluctuations and important events during big warm period of Holocene Epoch in China: China Science v. B, no. 12, pp. 1300-1308.

Shi Yafeng et al., 1993, Climate and environment in the prime of Holocene big warm period in China: China Science, pp. 865-872.

Wu Xihao et al., 1994, Temporal and spatial variations of east Asia summer wind during the climate suitable period of Holocene Epoch in China: Quaternary Research, no. 1, pp. 24-37.

Zhang Zonghu et al., 1983, Lithological and stratigraphic analysis of several profiles in Loess Plateau of China: Marine Geology and Quaternary Geology, v. 3, pp. 1-16.

Zhang Zonghu et al., 1989, Loess in China: Geological Publishing House, pp. 157-161; 198-204.

Zhou Tingru et al., 1992, Holocene environment evolution and its prediction in the crossed zone of cultivated land and pastry land in northern part of China: Geological Publishing House, pp. 1-69.

Zhu Kezhen, 1973, Preliminary study on climate variations of past five thousand years in China: China Science. 
Yun Chen, graduated from Nanjing University in 1961 and completed his postgraduate study in 1964. He is engaged in the study of Quaternary geology, as a research fellow of the Institute of Hydrogeology and Engineering Geology, Chinese Academy of Geological Sciences. He has published a number of important treatises and monographs on environmental geology, Quaternary geology and loess in China, and has won several scientific and technological achievement prizes.

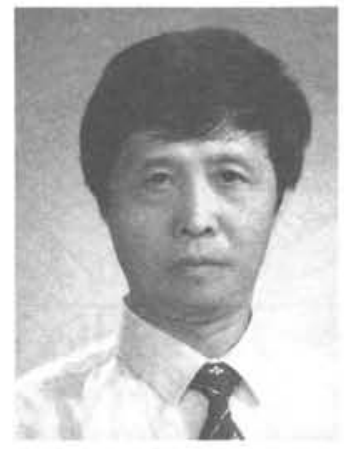

Zonghu Zhang, is an Academician of both the Chinese Academy of Sciences and the Chinese Academy of Engineering. He is Honorary Director and Professor of the Institute of Hydrogeology and Engineering Geology, Chinese Academy of Geological Sciences. For many years he has worked on hydrogeology, engineering geology and Quaternary geology and has undertaken deep and comprehensive research on loess in China. He has published many important monographs, treatises and maps, and has won a number of national scientific and technological achievement prizes.

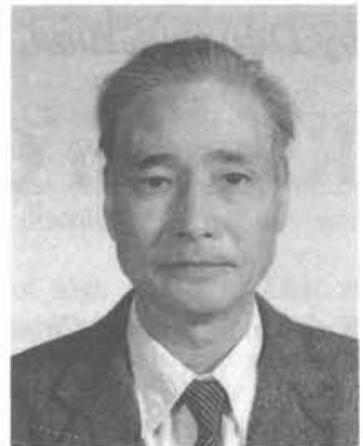

